\title{
-Original Article- \\ Changes in the Expression of Decoy Receptor 3 in Granulosa Cells During Follicular Atresia in Porcine Ovaries
}

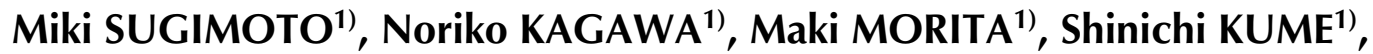 \\ Kannika WONGPANIT' ${ }^{2)}$, Huazi JIN ${ }^{2)}$ and Noboru MANABE ${ }^{2,3)}$

\begin{abstract}
${ }^{1)}$ Graduate School of Agriculture, Kyoto University, Kyoto 606-8502, ${ }^{2)}$ Animal Resource Science Center, Graduate School of Agricultural and Life Sciences, The University of Tokyo, Kasama 319-0206 and ${ }^{3)}$ Research Center for Food Safety, The University of Tokyo, Tokyo 113-8657, Japan
\end{abstract}

\begin{abstract}
During follicular development in mammalian ovaries, the majority of follicles undergo atresia. One of the characteristics of this process is apoptotic cell death in granulosa cells. Several death ligands and receptors, including Fas ligand (FasL) and Fas, have been detected in ovarian follicles and also demonstrated to be capable of inducing apoptosis in follicular cells. Decoy receptor 3 (DcR3) competes with Fas to bind FasL but lacks intracellular death domains, thus inhibiting the induction of apoptosis by the FasL/Fas system. In the present study, we examined the expression of putative porcine DcR3 (pDcR3) mRNA in porcine ovarian follicles. Total RNA was extracted from granulosa cells and thecal layer cells of tertiary follicles at healthy, early atretic and progressed atretic stages, and the expression of pDcR3 mRNA was demonstrated by reverse transcription-polymerase chain reaction (RT-PCR). The nucleic acid sequence in the coding region had $80 \%$ homology to that of human DcR3, and the deduced amino acid sequence was $73 \%$ identical to that of human DcR3. In an in situ hybridization experiment, pDcR3 mRNA expression was confirmed in granulosa and thecal layers, in both healthy and atretic follicles. Quantitative real time RT-PCR analysis showed that the expression of pDcR3 mRNA was weaker in granulosa cells of atretic follicles than those of healthy follicles. No notable changes were seen in the thecal layer cells. These results suggest that DcR3 plays a significant role in the regulation of apoptosis in granulosa cells, but not in thecal layer cells, during atresia.
\end{abstract}

Key words: Apoptosis, Decoy receptor-3 (DcR3), Follicular atresia, Granulosa cell, Porcine ovary

(J. Reprod. Dev. 56: 467-474, 2010)

n mammalian ovaries, the majority of follicles undergo a degenerative process known as atresia during follicular growth and maturation. Atretic follicles can be identified by their morphology, typically karyopyknosis in granulosa cells [1, 2]. Karyopyknosis is, however, also a typical morphological characteristic of apoptotic cells [3, 4]. Earlier studies [5, 6] have shown that degeneration of granulosa cells in atretic follicles is also associated with oligonucleosomal fragmentation of DNA, a biochemical hallmark of apoptosis, in agreement with the morphological observations. Our previous studies [7-11] demonstrated that porcine granulosa cells undergo apoptosis during follicular atresia through the histochemical and biochemical detection of DNA fragmentation and by electron microscopy. In antral follicles, apoptotic cells occurred at the inner surface of the granulosa layer at an early stage of follicular atresia and then diffused in the granulosa layer as atresia advanced. In thecal layer of atretic follicles, apoptotic cells were observed but at a low frequency compared with that in the granulosa layer.

Although it has been demonstrated that apoptotic cell death plays a significant role in ovarian follicular atresia, the mechanisms regulating apoptosis in granulosa cells are largely unclear. Apoptosis is classified into two types according to signal transduction

Received: March 3, 2010

Accepted: April 22, 2010

Published online in J-STAGE: June 1, 2010

(C)2010 by the Society for Reproduction and Development

Correspondence: N Manabe (e-mail: amanabe@mail.ecc.u-tokyo.ac.jp) pathways; one is membrane ligand/receptor-dependent, and the other is ligand/receptor and mitochondrion-dependent [12]. Ligand/receptor-dependent apoptosis is triggered by the association of death ligands with death receptors that are members of the tumor necrosis factor (TNF) superfamily and TNF receptor (TNFR) superfamily, respectively. To elucidate the contribution of TNF and TNFR superfamily proteins to porcine follicular atresia, we searched for porcine homologues of human death receptors in the expressed sequence tagged (EST) database and found a series of sequences whose deduced amino acid sequences showed homology to human decoy receptor 3 (DcR3, also known as TR6). The decoy receptors, which are also members of the TNFR superfamily, compete with the cell death receptors to bind the endogenous ligands, but lack an intracellular death domain (DD), thus modulating apoptotic signal transduction through the cell death receptors. DcR3 is one of the decoy receptors found in human carcinoma cells, that binds with Fas ligand (FasL, also known as Apo-1 ligand and CD95 ligand) and can inhibit the induction of apoptosis by the Fas FasL/Fas system, a representative death ligand and a death receptor system [13-16]. A broad range of human tumor cells have been reported to express DcR3 at high levels, and it is supposed that certain tumors may escape FasL/Fas-dependent immune-cytotoxic attack by expressing DcR3 [13, 14, 17-21]. DcR3 is also shown to bind with LIGHT (homologous to lymphotoxins, exhibits inducible expression, competes with herpes simplex virus glycoprotein D for HVEM, a receptor expressed by T lymphocytes) and TNF ligand-related molecule 1A (TL1A) and modulates their sig- 
nals [16, 22-25]. Although DcR3 mRNA has been detected in the chicken [26] and DcR3 has been predicted to exist in the chimpanzee and bovine genomic sequences, there has been no report on other mammalian orthologs of human DcR3 to date. Its intrinsic function, therefore, has not been wholly clarified.

In the present study, we identified the putative porcine DcR3 and examined changes in the expression and localization of DcR3 in porcine ovarian follicles during atresia by reverse transcriptionpolymerase chain reaction (RT-PCR) and in situ hybridization, respectively.

\section{Materials and Methods}

\section{Tissue collection}

As previously reported [27], ovaries obtained from gilts at a local slaughterhouse were used. For the isolation of total RNA, tertiary follicles (3-4 $\mathrm{mm}$ in diameter) were dissected out using scalpels and classified into the healthy, early atretic and progressed atretic stages based on their morphology under a dissection microscope. The primary feature of atretic follicles is the presence of cellular debris in granulosa cells, since it correlates with neutral $\mathrm{Ca}^{2+} / \mathrm{Mg}^{2+}$-dependent endonuclease activity [7] that catalyzes the internucleosomal cleavage of cellular DNA, which is characteristic of apoptosis. The granulosa layer and thecal layer were recovered from follicles at each stage by physical dissection, and total RNA was extracted from each sample using an RNeasy Mini Kit (Qiagen, Chatsworth, CA, USA). For preparation of histological sections, ovarian tissue pieces were frozen in 2-methyl butane, chilled with dry ice and kept at $-80 \mathrm{C}$.

\section{EST cloning, RT-PCR, $3^{\prime}$ - and 5'-rapid amplification of $c D N A$} ends ( $R A C E)$, and sequencing

A partial sequence of putative porcine DcR3 (pDcR3) was initially identified during a homology search in the EST database at the National Center for Biotechnology Information (US National Library of Medicine) using the amino acid sequence for human death receptor 6 (DR6) as a query. The EST sequence (GenBank accession number: CF788807) was about 30\% identical to human DR6. Another two EST sequences (CF361570 and CF362870) overlapping with the first sequence were found. These EST sequences were assembled, and an open reading frame (ORF) found in the assembled nucleotide sequence was transcribed into an amino acid sequence. There were six discrepant or undetermined nucleotides in the aligned EST sequences. Therefore, the deduced amino acid sequence contained two undetermined residues. A BLAST search revealed that this amino acid sequence had similarity to human DcR3.

The expression of pDcR3 in granulosa and thecal cells was examined by RT-PCR. The primers for RT-PCR, which were designed based on the sequence of pDcR3 using Primer3 [28], were as follows: 5'- CCA CTA CAC GCA GTT CTG GA-3', forward, and 5'- TGG AGG ACA AAT CCT GGA AA -3', reverse, with an expected PCR product size of 461 bp and representing the region from amino acid 72 to 224 of pDcR3. As templates, cDNAs were synthesized from total RNAs using a T-Primed First-Strand Kit (Amersham Pharmacia Biotech, Piscataway, NJ, USA). PCR was performed using Platinum Taq DNA Polymerase High Fidelity (Invitrogen, Carlsbad, CA, USA) with a PCRx Enhancer System (Invitrogen) in a thermal cycler (GeneAmp PCR Systems 9700; PE Applied Biosystems, Foster City, CA, USA). The hot-start PCR cycle was as follows: 2 min at $95 \mathrm{C}$, followed by 35 cycles of 30 sec at $95 \mathrm{C}, 30 \mathrm{sec}$ at $55 \mathrm{C}$ and $60 \mathrm{sec}$ at $68 \mathrm{C}$, and then a final extension period of $7 \mathrm{~min}$ at $68 \mathrm{C}$. To confirm the specific amplification of fragments of the expected size, each PCR product was electrophoresed in a $\%(\mathrm{w} / \mathrm{v})$ agarose gel (Sigma Aldrich Chemicals, St. Louis, MO, USA). The Ready-Load 100-bp DNA Ladder Marker (Gibco BRL, Grand Island, NY, USA) was used for electrophoresis. A representative PCR product was sequenced using an automatic DNA sequencer (ABI PRISM 310; PE Applied Biosystems) according to the manufacturer's instructions.

To obtain the full-length mRNA/cDNA sequence, 3'- and 5'RACE experiments were performed on RNA from granulosa cells using the 3'-RACE System for Rapid Amplification of cDNA Ends (Invitrogen) and 5'-RACE system, Version 2.0 (Invitrogen), respectively, according to the manufacturer's instructions. To overcome problems with in dC-tailing in 5'-RACE experiments, $10 \%(\mathrm{v} / \mathrm{v})$ dimethyl sulfoxide (DMSO) was added to the reaction mixture. In PCR amplification, the PCRx Enhancer System was used at variable strength. Amplified fragments were analyzed by $2 \%(\mathrm{w} / \mathrm{v})$ agarose gel electrophoresis and sequenced. The genespecific primers used in the 3'- and 5'-RACE experiments were as follows: 5'- CCA CTA CAC GCA GTT CTG GA -3', 3'-RACE; 5'- TGG AGG ACA AAT CCT GGA AA -3', first round 5'-RACE RT: 5'- CTC GAG CTG CTG TCT GAA AA -3', first round 5'RACE PCR: 5'- TCC AGA ACT GCG TGT AGT GG -3', second round 5'-RACE RT: 5'- CCA CAC ACC AGC CAC TCC -3', second round 5'-RACE PCR; and 5'- GGG TAG GTG GGT GCG TTC -3', second round 5'-RACE nested PCR. Sequences obtained in these experiments were analyzed using Genetyx-Mac, GenetyxMac/ATSQ and ClustalX (Software Development, Tokyo, Japan).

\section{In situ hybridization}

To reveal the localization of pDcR3 mRNA in the ovary, in situ hybridization was performed on frozen sections of porcine ovarian tissue using digoxygenin-labeled cRNA probes. As templates for cRNA probes, pDcR fragments and $\beta$-actin fragments were amplified by PCR using Platinum PCR supermix (Invitrogen). The primer pairs for partial cDNA sequences of pDcR3 were as follows: 5'- GGC ACC TTT TCA GAC AGC AG -3', forward, and 5'- TGG AGG ACA AAT CCT GGA AA -3', reverse, with an expected PCR product size of 223 bp. Those for $\beta$-actin were 5'TCC CTG GAG AAG AGC TAC GA -3', forward, and 5'- ACA TCT GCT GGA AGG TGG AC -3', reverse, with an expected PCR product size of $368 \mathrm{bp}$. The conditions for amplification were as follows: denaturation at $94 \mathrm{C}$ for $2 \mathrm{~min}$ and then 35 cycles of $94 \mathrm{C}$ for $30 \mathrm{sec}, 58 \mathrm{C}$ for $30 \mathrm{sec}$ and $72 \mathrm{C}$ for $30 \mathrm{sec}$. Amplified fragments were cloned into pDR-TOPO TA-cloning vector (Invitrogen) and reamplified using $\mathrm{T} 7$ promoter primer and each of the primers for amplification of $\mathrm{pDcR}$ and $\beta$-actin to prepare templates for sense and antisense probes. Digoxygenin (DIG)-labeled cRNA probes were synthesized by in vitro transcription using a DIG RNA Labelling Kit (Roche Diagnostics, Rotkreuz, Switzer- 
land). Tissue processing, hybridization and visualization were performed according to the manufacturer's directions. Frozen ovarian tissue pieces were cryosectioned at a thickness of $8 \mu \mathrm{m}$ and mounted on aminopropyltriethoxysilane-coated glass slides (Matsunami Glass, Osaka, Japan). Sections were soaked in xylene for 5 min to remove lipids and then air-dried. They were fixed with $4 \%$ (v/v) neutral buffered formalin (Wako, Osaka, Japan) for $7 \mathrm{~min}$, washed with PBS and washed in $2 \times$ standard saline citrate (SSC; Wako). The slides were prehybridized with $50 \%(\mathrm{v} / \mathrm{v})$ formamide hybridization cocktail (Amresco, Solon, OH, USA) for $1 \mathrm{~h}$ at $37 \mathrm{C}$. Hybridization (probe concentration, $100 \mathrm{ng} / \mathrm{ml}$ ) was performed at 37 C overnight. The sections were washed with $2 \times$ SSC three times for 5 min each, $0.2 \times$ SSC four times for 5 min each and $2 \times$ SSC three times for 5 min each at $37 \mathrm{C}$ and then equilibrated with 100 mM Tris-HCl, pH 7.5, containing 150 mM NaCl (THS). Sections were then treated with blocking solution (Roche) for $1 \mathrm{~h}$ at room temperature (22-25 C), incubated with alkaline phosphataseconjugated sheep anti-DIG antibody (diluted 1:200 with blocking solution; Roche) for $2 \mathrm{~h}$ at room temperature, washed with THS, and then incubated with a 5-bromo-4-chloro-3-indolyl phosphate and nitro blue tetrazolium chloride (BCIP/NBT) solution (BCIP/ NBT substrate system; Dako Cytomation, Glostrup, Denmark) containing $0.1 \mathrm{mM}$ levamisole (Dako Cytomation). The reaction was allowed to develop for $6.5 \mathrm{~h}$. The slides were washed in distilled water, lightly counterstained with methyl green, mounted in Ultramount (Dako Cytomation) and then examined under a light microscope.

\section{Quantitative real time $R T-P C R$}

Changes in pDcR3 mRNA/cDNA were examined by quantitative real-time PCR using a LightCycler system (Roche), according to the manufacturer's instructions. As an internal control, porcine $\beta$-actin mRNA/cDNA was also quantified. Reactions were performed in a $20 \mu \mathrm{l}$ reaction mixture (LightCycler Faststart DNA Master SYBR Green I; Roche) containing $0.5 \mathrm{mM}$ of each primer, nucleotides, Taq DNA Polymerase and $\mathrm{MgCl}_{2}$, whose optimized concentrations were $3 \mathrm{mM}$. DMSO $8 \%(\mathrm{v} / \mathrm{v})$ was added to the reaction mixture for amplification of $\mathrm{pDcR} 3$. The primer pairs for partial cDNA sequences of pDcR3 and $\beta$-actin were the same as those used in the amplification of templates for cRNA probes for in situ hybridization. The conditions for amplification were as follows: denaturation at $95 \mathrm{C}$ for $10 \mathrm{~min}$ and then 45 cycles of denaturation at $95 \mathrm{C}$ for $15 \mathrm{sec}$, annealing at $61 \mathrm{C}$ for $5 \mathrm{sec}$ and extension at $72 \mathrm{C}$ for $9 \mathrm{sec}$ for DcR3 and $95 \mathrm{C}$ for $10 \mathrm{~min}$, then 40 cycles of $95 \mathrm{C}$ for $15 \mathrm{sec}, 55 \mathrm{C}$ for $5 \mathrm{sec}$ and $72 \mathrm{C}$ for $9 \mathrm{sec}$ for $\beta$ actin. Quantification was performed using the LightCycler analysis software (Roche) on an IBM computer.

\section{Statistical analysis}

Results of quantitative RT-PCR were analyzed by one-way ANOVA and Scheffé's multiple comparison using StatView J-4.5 (Abacus Concepts, Berkeley, CA, USA) on a Macintosh computer. Differences at $\mathrm{P}<0.05$ were considered significant.

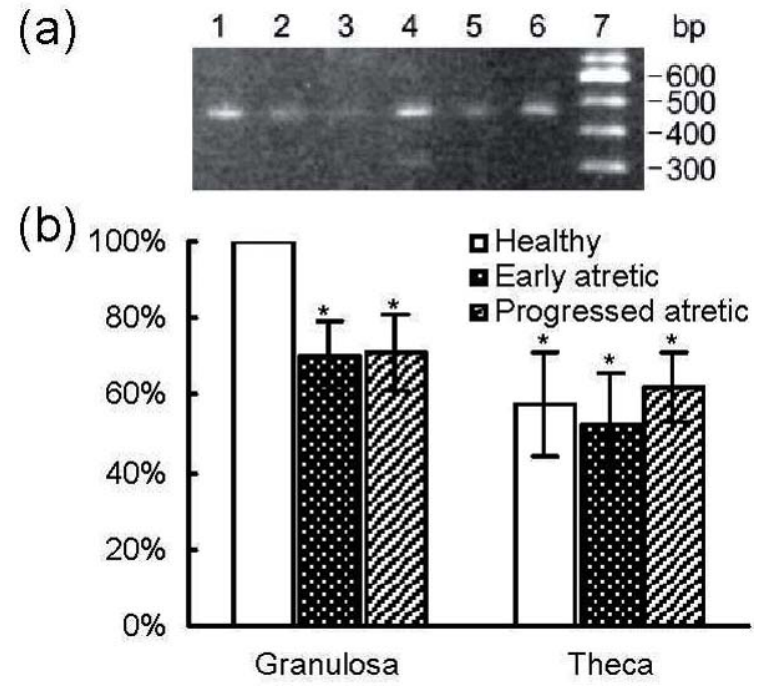

Fig. 1. (a): RT-PCR analysis of pDcR3 mRNA expression in granulosa and thecal layer cells. Fragments of the expected size (461 bp) were amplified in all groups. Lane 1: granulosa cells from healthy follicles. Lane 2: granulosa cells from early atretic follicles. Lane 3: granulosa cells from progressed atretic follicles. Lane 4: thecal layer from healthy follicles. Lane 5: thecal layer from early atretic follicles. Lane 6: thecal layer from progressed atretic follicles. Lane 7: 100-bp ladder marker. (b): Quantitative analysis of pDcR3 mRNA expression in granulosa and thecal layer cells by real-time RT-PCR. The expression level of pDcR3 was normalized to that of $\beta$-actin and presented as a percentage of that in the granulosa layer from healthy follicles. Results are expressed as the average \pm SD of four pairs of measurements.

\section{Results}

\section{Nucleic acid sequence and deduced amino acid sequence of pDcR3}

RT-PCR amplification, fragments of the expected size in all groups (Fig. 1a), and the nucleic acid sequence of the fragments corresponded with that found in the EST database. The nucleic acid sequence of pDcR3 mRNA/cDNA obtained by the 3'- and 5'RACE experiments spanned approximately $1.4 \mathrm{~kb}$ and contained an ORF for pDcR3 with a starting ATG at position 395 and a stop codon at nucleotide position 1,292 (Fig. 2). The similarity of pDcR3 to the human DcR3 variant M68C (GenBank accession number: NM 032945), which has a longer 5'-UTR than the variant M68E, was about 80\% within the ORF, whereas that in the 5'- and 3'- untranslated region (UTR) was only 50\%. The cDNA had a polyadenylation signal beginning at position 1,394.

The deduced amino acid sequence of pDcR3 (299 amino acid residues) was $73 \%$ identical (79\% similar) to that of human DcR3 (GenBank accession number: NP 003814) and 47\% identical (63\% similar) to that of chicken DcR3 (GenBank accession number: XP 417434, Fig. 3). The predicted chimpanzee DcR3 protein (GenBank accession number: XP 514789) consisted of 220 amino acid residues and showed high similarity to human DcR3 in the C-terminal region, but cysteine-rich repeats were not conserved. High 
gggtggacggggtct gtgtggcctgggcct ggtggtggggttgga gggcgccagagagga

110 tggggcetttgggca gtctgtctccgacct ggtttcaggggaggg gactccagcgcctct

170 gtcccactttgtcca gaagaggggggggcg coggggccccccag gaccgctctggggag

230 aagggggcatcccct gggacaaagcccgct ctccccogccccogc ccccccaggcaggga

290 gttgctgcccogggc ggggaggggaggggc tccgcgggggcgtgg ccagccoggccetta

350 taggacgcgcggtce ggcegccggcgccgc cgcagcagccagacc atgagggcccctccg M R A P P

410 tggcegtggccgtgg ccgctgccegccetg ctgctggcgttcaca gcgcgcggggaggcg

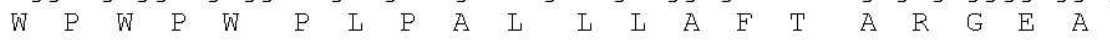

470 gcgaacgcacccacc tacccgtggcgggac gcggagaccggggag tggctggtgtgtggc $\begin{array}{llllllllllllllllllll}A & N & A & P & T & Y & P & W & R & D & A & E & T & G & E & W & L & V & C & G\end{array}$

530 cagtgccegcegggc accttcgtgcggegg cettgtggcceggac agccccacgacgtgc

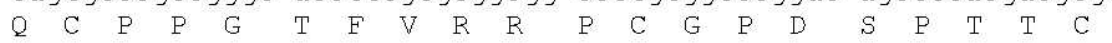

590 gacgcgtgcccgccg cgccactacacgcag ttctggaactacctg gagcgctgccggtac $\begin{array}{lllllllllllllllllllll}D & A & C & P & P & R & H & Y & T & Q & F & W & N & Y & L & E & R & C & R & Y\end{array}$

650 tgcaacgtcttctgc ggggagcgcgaggag gaggcgcggccgtgc ggggccacccacaac $\begin{array}{llllllllllllllllllllllllll}C & N & V & F & C & G & E & R & E & E & E & A & R & P & C & G & A & T & H & N\end{array}$

710 cgcgtctgcegctgt cgcccoggcttctc gcgcatgceggcttc tgcetggagcacgcg $\begin{array}{llllllllllllllllllllllll}R & V & C & R & C & R & P & G & F & F & A & H & A & G & F & C & L & E & H & A\end{array}$

770 ccetgcecgcetgge gccggcgtggeggec ctcggcaccccagc cagaacacgcagtgc

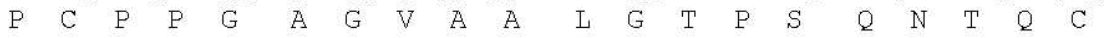

830 caggcgtgccccccg ggcaccttttcagac agcagctcgagttcg gagcagtgccggccc

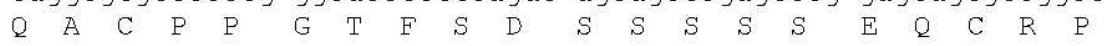

890 caccgcaactgcacg gccgtgggcctggce gtcaacgtgccgggc tcctccttccacgac

950 gcctgtgcaccaac tgcacgggcttccca ctcggctcgctggag cggggggcgccgggg 1009

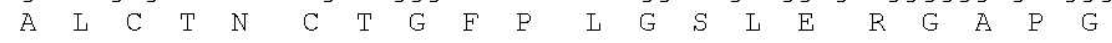

1010 accgaggagtgcgag cgcgctgtcgtcgac ttcgtagcttccag gatttgtcctccaag 1069 $\begin{array}{llllllllllllllllllllllll}T & E & E & C & E & R & A & V & V & D & F & V & A & F & Q & D & L & S & S & K\end{array}$

1070 aggctcctgcggctg cagcaggccctcgcc ggcccagggcegctg agtccgccgccgccg 1129 $\begin{array}{lllllllllllllllllllllllllllllllllll}R & L & L & R & L & Q & Q & A & L & A & G & P & G & P & L & S & P & P & P & P\end{array}$

1130 agggaggaccgcgcg gccetgcagctcagg ctgctgcgacagctc acggagctccgtgag 1189 $\begin{array}{llllllllllllllllllllllllllll}R & E & D & R & A & A & L & Q & L & R & L & L & R & Q & L & T & E & L & R & E\end{array}$

1190 gegcggcceggggeg ctggtggcgeggetg ctgceggcgctgcge acggccaggctgccg 1249

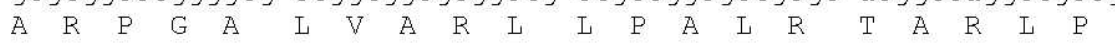

1250 gggetggagcgcgga gtccgcgcgcgcttc ctccgggegcgctga gcgccetcccogtta 1309 $\begin{array}{lllllllllllllllllllll}G & L & E & R & G & V & R & A & R & F & L & R & A & R & *\end{array}$

1310 tttattcgogcccog tcccagcgccccetg tgccgcatcgaagga ggcttctgccccggc 1369

1370 tcgggcggcgctaac tttattttataaag ccgattcctaaagga aaaaaaaaaaaa 1427

Fig. 2. Nucleic acid and deduced amino acid sequences of pDcR3. The asterisk at the end of the deduced amino acid sequence indicates the stop codon. A putative polyadenylation signal is underlined. 


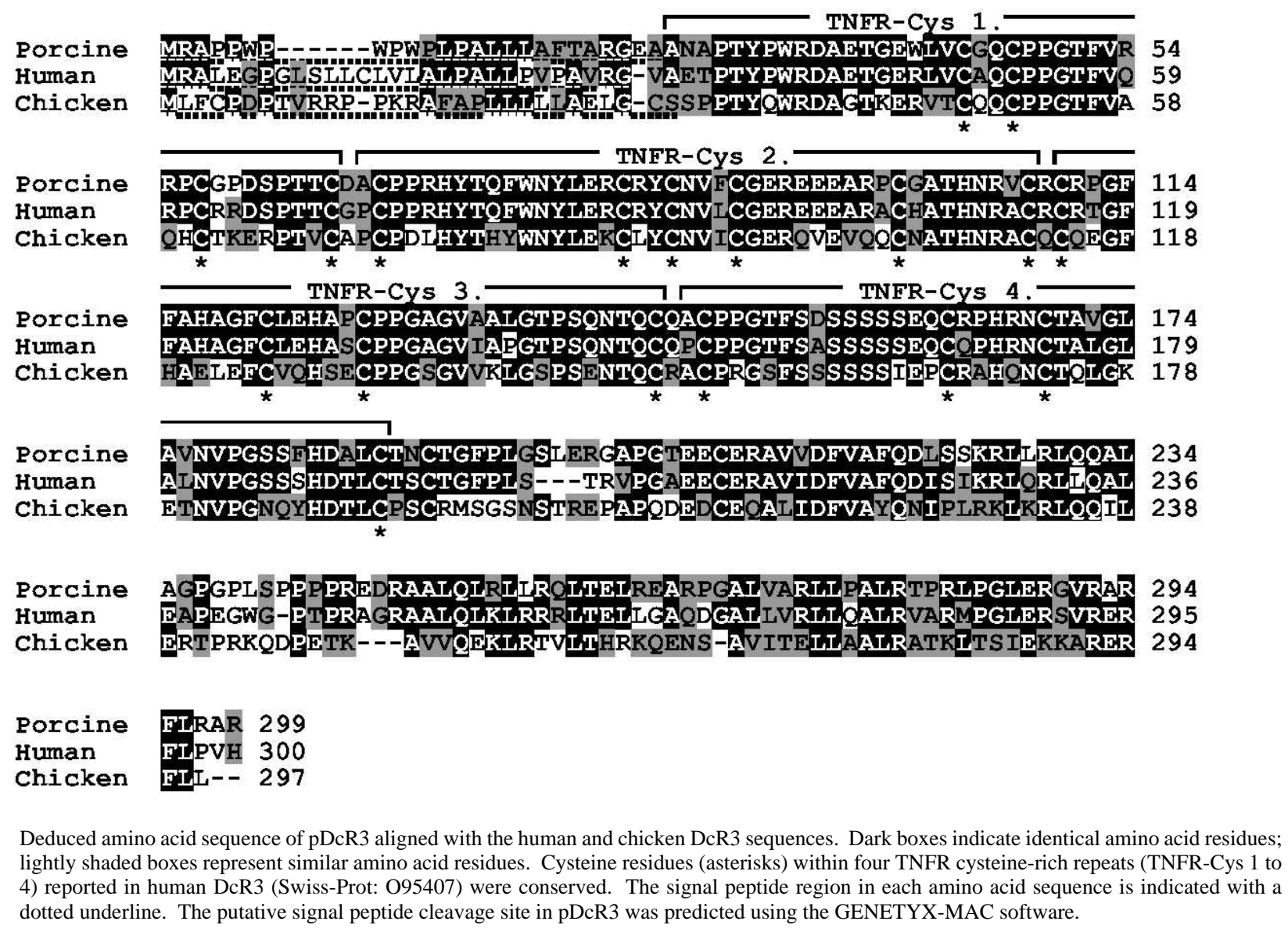

Fig. 3. Deduced amino acid sequence of pDcR3 aligned with the human and chicken DcR3 sequences. Dark boxes indicate identical amino acid residues; lightly shaded boxes represent similar amino acid residues. Cysteine residues (asterisks) within four TNFR cysteine-rich repeats (TNFR-Cys 1 to dotted underline. The putative signal peptide cleavage site in pDcR3 was predicted using the GENETYX-MAC software.

similarity (>90\%) was noted between the porcine and human sequences at amino acid residues corresponding to the four cysteine-rich repeats in human DcR3, and cysteine residues in these domains were conserved in pDcR3. Another ORF with a starting ATG at position 109 and a stop codon at nucleotide position 1,183 was found in the pDcR3 mRNA/cDNA. Part of the deduced amino acid sequence in the frame of the latter ORF showed moderate (43\% identical, $47 \%$ positive) homology to human regulator of telomere elongation helicase 1 (RTEL1) isoform 2 (GenBank accession number: NP 116575).

\section{Distribution of $p D c R 3 m R N A$ in ovarian follicles}

In situ hybridization experiments revealed the expression of pDcR3 mRNA in the granulosa and thecal layers of tertiary follicles (g and $\mathrm{t}$ in Fig. 4a, respectively). Expression was observed in granulosa layers of both healthy and atretic follicles $(\mathrm{H}$ and $\mathrm{A}$ in Fig. 4a, respectively), and no difference in expression level between healthy and atretic follicles was evident by in situ hybridization, which is not suitable for quantitative analysis.

\section{Changes in expression levels of $p D c R 3 m R N A$ during atresia}

As summarized in Fig. 1b, the normalized expression levels of pDcR3 mRNA were lower in granulosa cells prepared from early atretic and progressed atretic follicles than in those prepared from healthy follicles $(\mathrm{P}<0.05)$, whereas there was no notable difference in levels in the thecal layer cells between healthy and atretic follicles. Expression levels in thecal layer cells were lower than those in granulosa cells from healthy follicles $(\mathrm{P}<0.05)$ and similar to those in granulosa cells from atretic follicles.

\section{Discussion}

In the present study, pDcR3 mRNA expression in ovarian follicles was demonstrated. Analysis of the mRNA/cDNA sequence of pDcR3 revealed an alternative out-of-frame ORF starting upstream of the start codon for pDcR3. Several factors affecting the selection of a translation initiation site have been reported. The presence of a Kozak context is one of them. The nucleic acid sequence around the start codon of pDcR3 is a sub-optimal Kozak context (ACCATGA) identical to that in human DcR3, while the sequence around the start codon of the alternative ORF is an optimal Kozak context (AGGATGG). The variant M68C also has a start codon with a Kozak context (GGCATGG) at position 124, 311 bases upstream of the translation initiation site. It is supposed that there is some bias to select a downstream translation initiation site in human DcR3, and a similar phenomenon possibly occurs in pDcR3. In pDcR3, a stem-loop structure is expected around the start codon of the alternative ORF, which is a cause of the leaky 

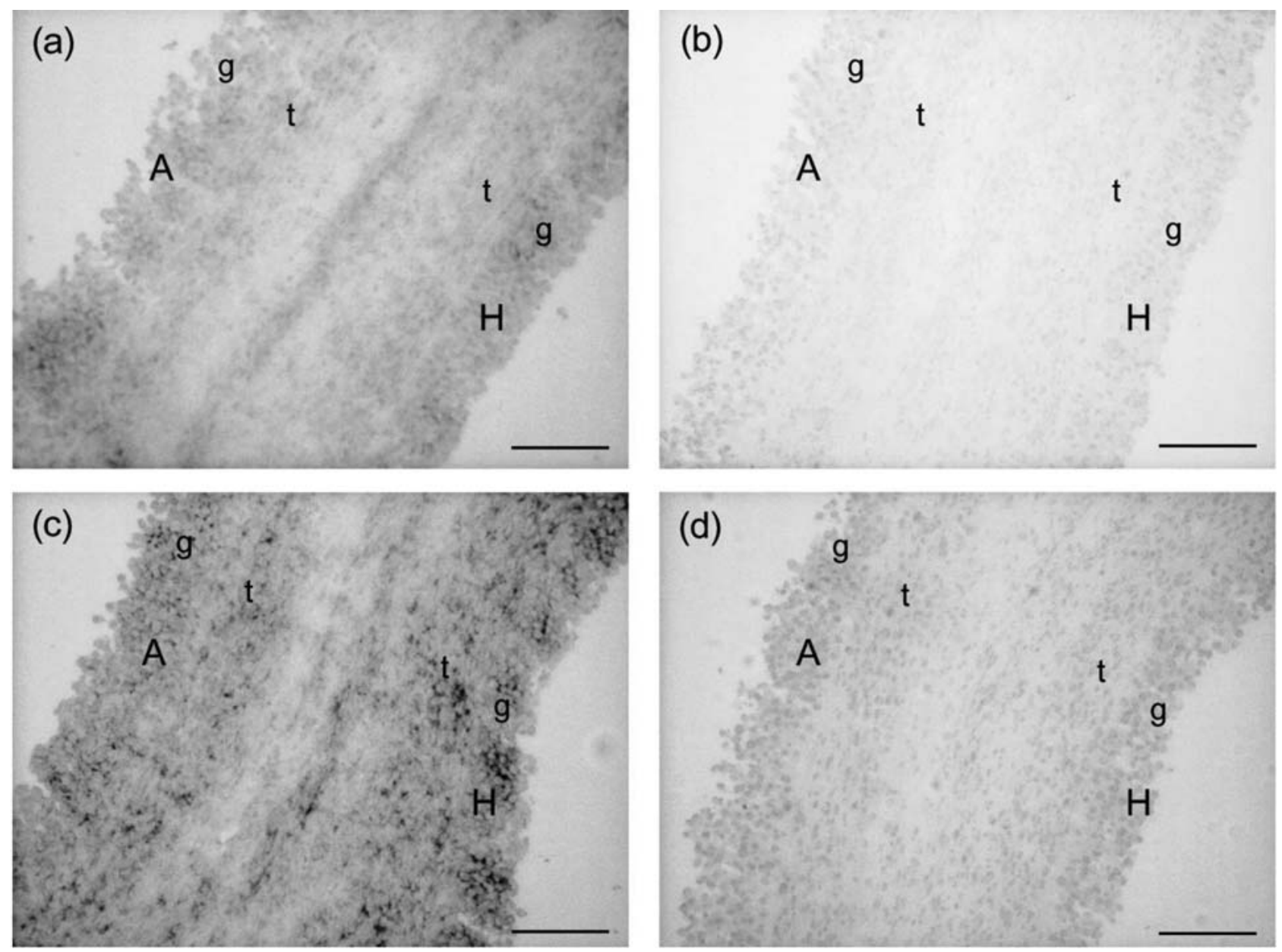

Fig. 4. Localization of pDcR3 mRNA expression demonstrated by in situ hybridization. Ovarian sections were hybridized with pDcR3 antisense probe (a), $\beta$-actin antisense probe (c) for a positive control, or pDcR3 sense (b) or $\beta$-actin sense (d) probe for a negative control. pDcR3 mRNA was expressed in granulosa layers of both healthy $(\mathrm{H})$ and atretic (A) follicles. g, granulosa layer; $\mathrm{t}$, theca interna. Bars=100 $\mu \mathrm{m}$.

scan.

In the human genome, DcR3 overlaps partially with the C-terminal coding region and 3'-UTR of RTEL1 isoform 2. The putative pDcR3 nucleic acid and deduced amino acid sequences showed similarities with those of human RTEL1 isoform 2 in the region overlapping with DcR3, in which the porcine and human DcR3 sequences have high similarity. It is doubtful that the pDcR3 sequence obtained in the present study is a partial sequence of the porcine RTEL1 homologue for two reasons; the stop codon in human RTEL1 isoform 2 was not conserved in the nucleic acid sequence of pDcR3, and the deduced amino acid sequence translated from the pDcR3 nucleic acid sequence in the reading frame corresponding to RTEL1 did not show significant similarity to human RTEL1 in the 5'-upstream region of pDcR3 mRNA/cDNA. It can not be denied that there are some alternatively spliced variants that produce the porcine RTEL1 homologue, which were not detected in the 5'-RACE experiments, and they have affected the quantitative analysis in the present study. For confirmation and further characterization of $\mathrm{pDcR}$, its protein expression should be proven.

Several death ligands and receptors have been detected in ovarian follicles and have been demonstrated to be capable of inducing apoptosis in follicular cells [10-12]. Our previous studies demonstrated that TNF superfamily and TNFR superfamily proteins are also expressed in porcine ovarian follicles and that they are involved in regulation of survival and apoptosis of granulosa cells [27, 29-32]. Not only death receptors, but also decoy receptors were expressed in porcine ovarian follicles. TNF-related apoptosis-inducing ligand (TRAIL) and its receptors, death receptor-4 (DR4), death receptor-5 (DR5) and decoy receptor-1 (DcR1), were expressed in porcine granulosa cells [29-31], and expression of DcR1 is reduced in granulosa cells in atretic follicles [31]. In addition, removal of DcR1 from the cellular surface sensitizes granulosa cells to TRAIL induced-apoptosis in vitro [30].

FasL and Fas has also been considered to participate in apoptosis during follicular atresia in the mammalian ovary, based on their expression in ovarian follicles [27, 33-42] and pro-apoptotic activities of FasL and antibodies to Fas in follicular cells. Increases in 
the expression of either or both of Fas and FasL have been observed during follicular atresia in mice [36], rats [37, 42], cattle [43] and pigs [27]. It has been reported that FasL was expressed in porcine granulosa cells and that its expression level and the percentage of apoptotic cells were increased by the effect of haem oxygenase, whose expression was increased in atretic follicles [44]. Fas and FasL are also expressed in normal follicles, although at lower levels compared with atretic follicles [27]. In addition, Fasmediated apoptosis is potentiated by cycloheximide in murine granulosa cells [45]. These findings suggest that follicular cells have certain inhibitors of Fas-mediated apoptosis. There are several reports on anti-apoptotic factors in ovarian follicles, including Fas-associated phosphatase (FAP-1) [45], members of the inhibitor of apoptosis protein (IAP) family [46-49] and cellular FLICE-like inhibitory protein (c-FLIP) [50-58]. Their participation in the apoptosis of granulosa cells and follicular atresia has been suggested, although their significance in the regulation of follicular atresia in vivo remains to be clarified.

In the present study, the expression level of pDcR3 mRNA in granulosa and thecal layers in both healthy and atretic follicles was demonstrated by RT-PCR and in situ hybridization experiments. Quantitative RT-PCR analysis showed the expression level to be lower in granulosa cells prepared from atretic follicles than in those prepared from healthy follicles, but no notable changes were seen in the thecal layer cells. These results suggest that DcR3 plays a significant role in the regulation of apoptosis in granulosa cells, but not in thecal layer cells, during follicular atresia. The expression of the DcR3 homologue in the ovary has been reported in chickens and Northern blotting showed increased expression of DcR3 in atretic follicles [59]. The granulosa layer and thecal layer were not separated in that study, and so, the results cannot be directly compared to our results. DcR3 can inhibit Fas-mediated apoptosis, therefore, pDcR3 would play a significant role in the regulation of apoptosis relevant to follicular atresia in porcine granulosa cells. Although the expression of pDcR3 mRNA in the granulosa layer decreased in atretic follicles, the levels were still detectable. It is possible that some death ligand/receptor systems other than the FasL/Fas system [27], presumably the TRAIL/DR4 and DR5 systems [29-31], but not the TNF $\alpha / T N F R 2$ system [12, 32], are the main inducers of the receptor-mediated apoptosis of granulosa cells during follicular atresia in porcine ovaries.

In another set of in situ hybridization experiments, positive signals were observed in corpora lutea, but non-specific signals were also noted in this region. The FasL/Fas system plays a central role in the apoptosis of luteal cells during luteolysis [60]. Our previous study showed that the expression of soluble-Fas (FasB), which antagonizes FasL signaling, regulates luteolysis in murine ovaries [61]. In the ovaries, pDcR3 might inhibit FasL before starting luteolysis in the same manner cFLIP [62]. The expression and function of the FasL/Fas system in luteolysis in porcine ovaries, as well as pDcR3, need to be elucidated.

It has been reported that human DcR3 over-expressed in mice functions as a decoy for endogenous FasL [63], but its intrinsic function has not been clarified since knockout animal experiments have not been carried out. We have not yet revealed the properties of pDcR3 protein; therefore, it is still unclear whether or not pDcR3 has similar properties to human DcR3. If pDcR3 is the functional homologue of human DcR3, clarification its physiological function will be possible by generation and analysis of DcR3 knockout pigs.

In conclusion, DcR3 mRNA was localized in the granulosa and thecal layers of both healthy and atretic follicles in porcine ovarian follicles. Lower levels of DcR3 mRNA were noted in granulosa cells prepared from atretic follicles than in those prepared from healthy follicles, but no notable changes in DcR3 mRNA were seen in the thecal layer cells during atresia. These present results suggest that DcR3 plays a significant role in the regulation of apoptosis in granulosa cells, but not in thecal layer cells, during atresia.

\section{Acknowledgements}

This study was supported by a Grant-in-Aid for Creative Scientific Research 13GS0008 to NM from the Ministry of Education, Culture, Sports, Science and Technology of Japan, by Grants-inAid for Challenging Exploratory Research 18658105 and 21658092 and Scientific Research B18380164, B22380148 and S16108003 to NM from the Japan Society for the Promotion of Science, and by Grant-in-Aid for Food Safety Assessment 0804 from the Food Safety Commission of Japan.

\section{References}

1. Byskov AG. Cell kinetic studies of follicular atresia in the mouse ovary. J Reprod Fertil 1974; 37: 277-285.

2. Hay MR, Cran DG, Moor RM. Structural changes occurring during atresia in sheep ovarian follicles. Cell Tissue Res 1976; 169: 515-529.

3. Kerr JF, Wyllie AH, Currie AR. Apoptosis: A basic biological phenomenon with wide-ranging implications in tissue kinetics. Br J Cancer 1972; 26: 239-257.

4. Wyllie AH, Kerr JF, Currie AR. Cell death: The significance of apoptosis. Int Rev Cytol 1980; 68: 251-306.

5. Hughes FM, Gorospe WC. Biochemical identification of apoptosis (programmed cell death) in granulosa cells: evidence for a potential mechanism underlying follicular atresia. Endocrinology 1991; 129: 2415-2422.

6. Tilly JL. Apoptosis and ovarian function. Rev Reprod 1996; 1: 162-172.

7. Manabe N, Imai Y, Ohno H, Takahagi Y, Sugimoto M, Miyamoto H. Apoptosis occurs in granulosa cells but not cumulus cells in the atretic antral follicles in pig ovaries. Experientia 1996; 52: 647-651.

8. Sugimoto M, Manabe N, Kimura $\mathbf{Y}$, Myomoto A, Imai $\mathbf{Y}$, Ohno $\mathbf{H}$, Miyamoto $\mathbf{H}$ Ultrastructural changes in granulosa cells in porcine antral follicles undergoing atresia indicate apoptotic cell death. J Reprod Dev 1998; 44: 7-14.

9. Nakayama M, Manabe N, Nishihara S, Miyamoto H. Species specific differences in apoptotic cell localization in granulosa and theca interna cells during follicular atresia in porcine and bovine ovaries. J Reprod Dev 2000; 46: 147-156.

10. Manabe N, Inoue N, Miyano T, Sakamaki K, Sugimoto M, Miyamoto H. Ovarian follicle selection in mammalian ovaries. In: Leung PK, Adashi E (eds.), The Ovary $2^{\text {nd }}$ ed. Amsterdam: Academic Press; 2003: 369-385.

11. Manabe N, Goto Y, Matsuda-Minehata F, Inoue N, Maeda A, Sakamaki K, Miyano T. Regulation mechanism of selective atresia in porcine follicles: Regulation of granulosa cell apoptosis during atresia. J Reprod Dev 2004; 50: 493-514.

12. Manabe N, Matsuda F, Goto Y, Maeda A, Cheng Y, Nakagawa N, Inoue N, Wongpanit K, Jin H, Gonda H, Li J. Role of cell death ligand and receptor system on regulation of follicular atresia in pig ovaries. Reprod Dom Anim 2008; 43: 268-272.

13. Pitti RM, Marsters SA, Lawrence DA, Roy M, Kischkel FC, Dowd P, Huang A, Donahue CJ, Sherwood SW, Baldwin DT, Godowski PJ, Wood WI, Gurney AL, Hillan KJ, Cohen RL, Goddard AD, Botstein D, Ashkenazi A. Genomic amplification of a decoy receptor for Fas ligand in lung and colon cancer. Nature 1998; 396: 699-703.

14. Roth W, Isenmann S, Nakamura M, Platten M, Wick W, Kleihues P, Bahr M, Ohgaki H, Ashkenazi A, Weller M. Soluble decoy receptor 3 is expressed by malignant gliomas and suppresses CD95 ligand-induced apoptosis and chemotaxis. Cancer Res 2001; 61: 2759-2765.

15. Connolly K, Cho YH, Duan R, Fikes J, Gregorio T, LaFleur DW, Okoye Z, Salcedo TW, Santiago G, Ullrich S, Wei P, Windle K, Wong E, Yao XT, Zhang YQ, Zheng G, 
Moore PA. In vivo inhibition of Fas ligand-mediated killing by TR6, a Fas ligand decoy receptor. J Pharmacol Exp Ther 2001; 298: 25-33.

16. Wroblewski VJ, Witcher DR, Becker GW, Davis KA, Dou S, Micanovic R, Newton CM, Noblitt TW, Richardson JM, Song HY, Hale JE. Decoy receptor 3 (DcR3) is proteolytically processed to a metabolic fragment having differential activities against Fas ligand and LIGHT. Biochem Pharmacol 2003; 65: 657-667.

17. Tsuji S, Hosotani R, Yonehara S, Masui T, Tulachan SS, Nakajima S, Kobayashi H, Koizumi M, Toyoda E, Ito D, Kami K, Mori T, Fujimoto K, Doi R, Imamura M. Endogenous decoy receptor 3 blocks the growth inhibition signals mediated by Fas ligand in human pancreatic adenocarcinoma. Int J Cancer 2003; 106: 17-25.

18. Takahama $Y$, Yamada $Y$, Emoto $K$, Fujimoto $H$, Takayama T, Ueno $M$, Uchida $H$, Hirao S, Mizuno T, Nakajima Y. The prognostic significance of overexpression of the decoy receptor for Fas ligand (DcR3) in patients with gastric carcinomas. Gastric Cancer 2002; 5: 61-68.

19. Bai C, Connolly B, Metzker ML, Hilliard CA, Liu X, Sandig V, Soderman A, Galloway SM, Liu Q, Austin CP, Caskey CT. Overexpression of M68/DcR3 in human gastrointestinal tract tumors independent of gene amplification and its location in a fourgene cluster. Proc Natl Acad Sci USA 2000; 97: 1230-1235.

20. Ohshima K, Haraoka S, Sugihara M, Suzumiya J, Kawasaki C, Kanda M, Kikuchi M. Amplification and expression of a decoy receptor for Fas ligand (DcR3) in virus (EBV or HTLV-I) associated lymphomas. Cancer Lett 2000; 160: 89-97.

21. Elnemr A, Ohta T, Yachie A, Kayahara M, Kitagawa H, Fujimura T, Ninomiya I, Fushida S, Nishimura GI, Shimizu K, Miwa K. Human pancreatic cancer cells disable function of Fas receptors at several levels in Fas signal transduction pathway. Int JOncol 2001; 18: 311-316.

22. Yang CR, Hsieh SL, Teng CM, Ho FM, Su WL, Lin WW. Soluble decoy receptor 3 induces angiogenesis by neutralization of TL1A, a cytokine belonging to tumor necrosis factor superfamily and exhibiting angiostatic action. Cancer Res 2004; 64: 1122-1129.

23. Migone TS, Zhang J, Luo X, Zhuang L, Chen C, Hu B, Hong JS, Perry JW, Chen SF, Zhou JX, Cho YH, Ullrich S, Kanakaraj P, Carrell J, Boyd E, Olsen HS, Hu G, Pukac L, Liu D, Ni J, Kim S, Gentz R, Feng P, Moore PA, Ruben SM, Wei P. Tl1a is a TNFlike ligand for DR3 and TR6/DcR3 and functions as a T cell costimulator. Immunity 2002; 16: 479-492.

24. Yu KY, Kwon B, Ni J, Zhai Y, Ebner R, Kwon BS. A newly identified member of tumor necrosis factor receptor superfamily (TR6) suppresses light-mediated apoptosis. J Biol Chem 1999; 274: 13733-13736.

25. Gill RM, Hunt JS. Soluble receptor (DcR3) and cellular inhibitor of apoptosis-2 (CIAP-2) protect human cytotrophoblast cells against LIGHT-mediated apoptosis. Am J Pathol 2004; 165: 309-317.

26. Bridgham JT, Johnson AL. Characterization of chicken TNFR superfamily decoy receptors, DcR3 and osteoprotegerin. Biochem Biophys Res Comm 2003; 307: 956-961.

27. Inoue N, Maeda A, Matsuda-Minehata F, Fukuta K, Manabe N. Expression and localization of Fas ligand and Fas during atresia in porcine ovarian follicles. J Reprod Dev 2006; 52: 723-730.

28. Rozen S, Skaletsky H. Primer3 on the www for general users and for biologist programmers. In: Krawetz S, Misener S (eds.), Bioinformatics Methods and Protocols: Methods in Molecular Biology. Totowa, NJ: Humana Press; 2000: 365-386.

29. Inoue N, Manabe N, Matsui T, Maeda A, Nakagawa S, Wada S, Miyamoto H. Roles of tumor necrosis factor-related apoptosis-inducing ligand signaling pathway in granulosa cell apoptosis during atresia in pig ovaries. J Reprod Dev 2003; 49: 313-321.

30. Wada S, Manabe N, Nakayama M, Inou N, Matsui T, Miyamoto H. Trail-decoy receptor 1 plays inhibitory role in apoptosis of granulosa cells from pig ovarian follicles. J Vet Med Sci 2002; 64: 435-439.

31. Wada S, Manabe N, Inoue N, Nakayama M, Matsui T, Miyamoto H. TRAIL-decoy receptor-1 disappears in granulosa cells of atretic follicles in porcine ovaries. J Reprod Dev 2002; 48: 167-173.

32. Nakayama M, Manabe $\mathbf{N}$, Inoue N, Matsui T, Miyamoto $\mathbf{H}$. Changes in the expression of tumor necrosis factor (TNF) $\alpha$, TNF $\alpha$ receptor (TNFR) 2, and TNFR-associated factor 2 in granulosa cells during atresia in pig ovaries. Biol Reprod 2003; 68: 530-535.

33. Quirk SM, Cowan RG, Joshi SG, Henrikson KP. Fas antigen-mediated apoptosis in human granulosa/luteal cells. Biol Reprod 1995; 52: 279-287.

34. Hakuno N, Koji T, Yano T, Kobayashi N, Tsutsumi O, Taketani Y, Nakane PK. Fas/ Apo-1/CD95 system as a mediator of granulosa cell apoptosis in ovarian follicle atresia. Endocrinology 1996; 137: 1938-1948.

35. Sakamaki K, Yoshida H, Nishimura Y, Nishikawa S, Manabe N, Yonehara S. Involvement of Fas antigen in ovarian follicular atresia and luteolysis. Mol Reprod Dev 1997; 47: 11-18.

36. Xu JP, Li X, Mori E, Sato E, Saito S, Guo MW, Mori T. Expression of Fas-Fas ligand system associated with atresia in murine ovary. Zygote 1997; 5: 321-327.

37. Kim JM, Boone DL, Auyeung A, Tsang BK. Granulosa cell apoptosis induced at the penultimate stage of follicular development is associated with increased levels of Fas and Fas ligand in the rat ovary. Biol Reprod 1998; 58: 1170-1176.
38. Cataldo NA, Dumesic DA, Goldsmith PC, Jaffe RB. Immunolocalization of Fas and Fas ligand in the ovaries of women with polycystic ovary syndrome: Relationship to apoptosis. Hum Reprod 2000; 15: 1889-1897.

39. Vickers SL, Cowan RG, Harman RM, Porter DA, Quirk SM. Expression and activity of the Fas antigen in bovine ovarian follicle cells. Biol Reprod 2000; 62: 54-61.

40. Porter DA, Vickers SL, Cowan RG, Huber SC, Quirk SM. Expression and function of Fas antigen vary in bovine granulosa and theca cells during ovarian follicular development and atresia. Biol Reprod 2000; 62: 62-66.

41. Quirk SM, Cowan RG, Harman RM. The susceptibility of granulosa cells to apoptosis is influenced by oestradiol and the cell cycle. J Endocrinol 2006; 189: 441-453.

42. Honnma $\mathbf{H}$, Endo $T$, Henmi $H$, Nagasawa $K$, Baba T, Yamazaki $K$, Kitajima $\mathbf{Y}$, Hayashi T, Manase K, Saito T. Altered expression of Fas/Fas ligand/caspase 8 and membrane type 1-matrix metalloproteinase in atretic follicles within dehydroepiandrosterone-induced polycystic ovaries in rats. Apoptosis 2006; 11: 1525-1533.

43. Porter DA, Harman RM, Cowan RG, Quirk SM. Relationship of Fas ligand expression and atresia during bovine follicle development. Reproduction 2001; 121: 561-566.

44. Harada T, Koi H, Kubota T, Aso T. Haem oxygenase augments porcine granulosa cell apoptosis in vitro. J Endocrinol 2004; 181: 191-205.

45. Quirk SM, Porter DA, Huber SC, Cowan RG. Potentiation of Fas-mediated apoptosis of murine granulosa cells by interferon- $\gamma$, tumor necrosis factor- $\alpha$, and cycloheximide. Endocrinology 1998; 139: 4860-4869.

46. Li J, Kim JM, Liston P, Li M, Miyazaki T, Mackenzie AE, Korneluk RG, Tsang BK Expression of inhibitor of apoptosis proteins (IAPs) in rat granulosa cells during ovarian follicular development and atresia. Endocrinology 1998; 139: 1321-1328.

47. Matsumoto K, Nakayama T, Sakai H, Tanemura K, Osuga H, Sato E, Ikeda JE. Neuronal apoptosis inhibitory protein (NAIP) may enhance the survival of granulosa cells thus indirectly affecting oocyte survival. Mol Reprod Dev 1999; 54: 103-111.

48. Xiao CW, Ash K, Tsang BK. Nuclear factor-кB-mediated X-linked inhibitor of apoptosis protein expression prevents rat granulosa cells from tumor necrosis factor $\alpha$ induced apoptosis. Endocrinology 2001; 142: 557-563.

49. Cheng Y, Maeda A, Goto Y, Matsuda F, Miyano T, Inoue N, Sakamaki K, Manabe N. Changes in expression and localization of $X$-linked inhibitor of apoptosis protein (XIAP) in follicular granulosa cells during atresia in porcine ovaries. J Reprod Dev 2008; 54: 454-459.

50. Goto Y, Matsuda F, Inoue N, Matsui T, Maeda A, Manabe N. Porcine (Sus scrofa) cellular FLICE-like inhibitory protein (cFLIP): Molecular cloning and comparison with the human and murine cFLIP. J Reprod Dev 2004; 50: 549-555.

51. Matsuda-Minehata F, Goto Y, Inoue N, Manabe N. Changes in expression of antiapoptotic protein, cFLIP, in granulosa cells during follicular atresia in porcine ovaries. Mol Reprod Dev 2005; 72: 145-151.

52. Matsuda F, Inoue N, Goto $\mathbf{Y}$, Manabe N. The regulation of ovarian granulosa cell death by pro- and anti-apoptotic molecules. J Reprod Dev 2006; 52: 695-705.

53. Matsuda F, Goto Y, Inoue N, Sakamaki K, Chedrese PJ, Manabe N. Anti-apoptotic activity of porcine cFLIP in ovarian granulosa cell lines. Mol Reprod Dev 2007; 73: 11651170 .

54. Inoue N, Matsuda F, Goto Y, Sakamaki K, Manabe N. Molecular characteristics of porcine Fas-associated death domain (FADD) and procaspase-8. J Reprod Dev 2007; 53 427-436.

55. Maeda A, Goto Y, Matsuda F, Cheng Y, Inoue N, Manabe N. Changes in expression of interleukin-6 receptors in granulosa cells during follicular atresia in pig ovaries. Reprod Dev 2007; 53: 481-490.

56. Maeda A, Matsuda F, Cheng Y, Inoue N, Manabe N. The role of interleukin-6 in the regulation of granulosa cell apoptosis during follicular atresia in pig ovaries. J Reprod Dev 2007; 53: 727-736.

57. Matsuda F, Maeda A, Cheng Y, Sai T, Gonda H, Manabe N. Regulation of granulosa cell apoptosis by death ligand-receptor signaling. Anim Sci J 2008; 79: 1-10.

58. Matsuda F, Inoue N, Goto Y, Maeda A, Cheng Y, Sakamaki K, Manabe N. cFLIP regulates death receptor-mediated apoptosis in an ovarian granulosa cell line by inhibiting procaspase-8 cleavage. J Reprod Dev 2008; 54: 314-320.

59. Bridgham JT, Johnson AL. Characterization of chicken TNFR superfamily decoy receptors, DcR3 and osteoprotegerin. Biochem Biophys Res Commun 2003; 307: 956-961.

60. Komatsu K, Manabe N, Kiso M, Shimabe M, Miyamoto H. Changes in localization of immune cells and cytokines in corpora lutea during luteolysis in murine ovaries. J Exp Zool 2003; 296: 152-159.

61. Komatsu K, Manabe N, Kiso M, Shimabe M, Miyamoto H. Soluble Fas (FasB) regulates luteal cell apoptosis during luteolysis in murine ovaries. Mol Reprod Dev 2003; 65 345-352

62. Hojo T, Al-Zi'abi MO, Komiyama J, Manabe N, Acosta TJ, Okuda K. Expression and localization of cFLIP, an anti-apoptotic factor, in the bovine corpus luteum. J Reprod Dev 2010; 56: 230-235.

63. Burz C, Berindan-Neagoe I, Balacescu O, Irimie A. Apoptosis in cancer: Key molecular signaling pathways and therapy targets. Acta Oncol 2009, 48: 811-821. 